\title{
Seeing Beyond: Movies, Visions, and Values
}

\author{
By Gerald Pratley
}

Spring 2002 Issue of KINEMA

THIS remarkable compilation is filled from cover to cover with 26 thoughtful and enlightening essays on a wide range of genres and master-directors, by 15 different authors, after which 14 more authors, mostly film professors, weigh in with their writings on theory, criticism and just about every other aspect of what the movies mean, joining the other writers in rethinking how we see movies, audiences, other critics, and ourselves in this fascinating world of art, morality and humanistic values. Most of the writers are Mr. Robinson's friends. He himself is much admired as a pioneer in film studies, and was a great influence on Richard Sugg who edited this tremendous out-pouring of exactly what do movies teach us exploring a very large number and range of classic and modern films, with a generous number of directors from Ford to Fellini.

Don't expect however, to find David Lean, one of world's finest filmmakers, but then we cannot have everything even among the hundreds. To name all the contributors would take up more space that we have and to name only a few would be unfair to those left out. In making one's way through this perceptive and thoughtful examination of what cinema stands for there are many posts, related to - auteurism, indivualization, modernism, structuralists, and reproduction. But do not weary for on reaching the end readers will find themselves in a state of exultation, excitement and wonder at what may be found in the realm of film study in all the compelling aspects of academic discourse, arguments included.

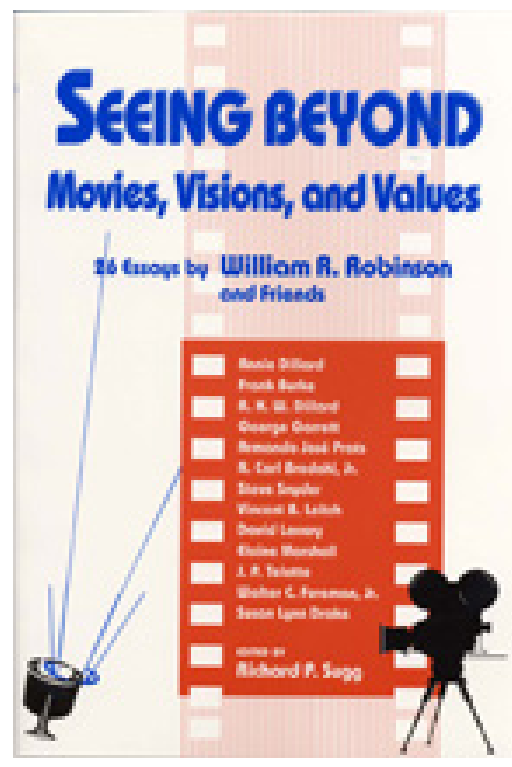

Figure 1: BY: William R. Robinson and His Friends. ๆ PUBLISHER: Golden String Press NY ๆ YEAR: 2002 ๆ PAGES: 488pp ๆ ISBN: 0-970678-1-6

\section{References}

\section{PERIES - WILLIE BLAKE AWARD}

It has come to our attention that the famed Sri Lankan director, Lester James Peries and his brilliant cinematographer, Willie Blake, have each been presented with "The Golden Lion", the Presidential Life Achievement Award, by the National Film Corporation of Sri Lanka for Cinematic Excellence during their 50 Years of Sri Lankan filmmaking. Peries is well-known for his Gamperaliya (Changing Village, 1965), among his many other works, and Blake, who began his career as a second unit cameraman on David Lean's The Bridge on the River Kwai, filmed entirely in the then Ceylon, has since lived in Toronto dividing his time 
between his native land and making fine documentaries around the world for The Craven Film Corp of New York. Our congratulations to them.

\section{Author Information}

Gerald PRATLEY, OC, LLD, started his career as film critic with the CBC. In 1969, he founded the Ontario Film Institute which he directed until 1990. He has written several books and numerous articles on film, including Torn Sprockets, a history of Canadian cinema. He taught Film History in universities in Toronto and Waterloo, Canada and holds three honorary degrees from Canadian and US universities.

Gerald A. Pratley (1923-2011) was born and educated in London, England, and came to Canada in 1946. He started working in Toronto for the $\mathrm{CBC}$ as a scriptwriter. He was drawn toward working in motion pictures, and became, in 1948, the CBC's first film critic and commentator.

Gerald Pratley broadcast three programmes a week, Pratley at the Movies, The Movie Scene, Music From the Films, and others, until 1975. During this time he also became the first post-war chairman of the Toronto Film Society, chairman of the Toronto and District Film Council and co-founder of the A-G-E Film Society and correspondent for international magazines such as Films and Filming, Film In Review, Variety, Hollywood Quarterly and International Film Guide. During the 1950s he wrote for Canadian Film Weekly and Canadian Film Digest.

He became known as a speaker on all aspects of motion picture art and industry, and was invited to teach film history at the University of Toronto, York University, University of Waterloo, Seneca College and Ryerson Polytechnical University, with individual lectures being given at many other Canadian and US universities and colleges. He has served as a member of various judging panels of competitions and festivals, being one of the members of the first Canadian Film Awards in 1949.

From 1970 to 1975 he was the director of the Stratford (Ontario) International Film Festival, and from 1969 to 1976 he was Chairman of the International Jury of the Canadian Film Awards. He has attended all the world's leading festivals of film, and in particular, for 30 years, the Cannes Festival as CBC correspondent. He has written six books, The Films of Frankenheimer: Forty Years in Film; The Cinema of John Frankenheimer; The Cinema of Otto Preminger; The Cinema of David Lean; The Cinema of John Huston, and Torn Sprockets, a history of the Canadian cinema.

Gerald Pratley has served on the Advisory Boards of the film departments of Ryerson Polytechnical University and Humber College, and as a member of the programme committee of TV Ontario. In 1968 he became the founder-director of the Ontario Film Institute of the Province of Ontario, an organization which has distinguished itself in archival holdings and public service and is known since 1990 as the Cinematheque of Ontario. He taught Film History courses at the Department of Film and Photography, Ryerson Polytechnic University, Toronto and the University of Waterloo.

In 1984, Gerald Pratley was made a Member of the Order of Canada and in 2003 Officer of the Order of Canada for his service to Canada through film appreciation. He holds Honorary Degrees in Letters and Fine Arts from York and Waterloo Universities (Ont., Canada) and Bowling Green State University (Ohio, USA).

In 2002, Gerald Pratley received a Special Genie Award from the Academy of Canadian Cinema \& Television in recognition of his lifelong dedication to the promotion and his exceptional support of Canadian cinema.

He died on 14 March 2011 in Ontario, Canada. 